\title{
First Report of Echthrogaleus denticulatus (Smith 1874) on the Pelagic Thresher Shark (Alopias pelagicus Nakamura 1935) from Indian EEZ of Andaman Sea (Laporan Pertama Echthrogaleus denticulatus (Smith, 1874) pada Pelagik Yu Ekor Panjang (Alopias pelagicus Nakamura 1935) dari EEZ India Laut Andaman)
}

PRADEEP, H.D.*, ARUN KUMAR, M. \& SWAPNIL, S.S.

\begin{abstract}
The present study reports the occurrence of the pandarid parasite, Echthrogaleus denticulatus as an ectoparasite on the pelagic thresher shark (Alopias pelagicus) from the Indian EEZ of Andaman Sea. A total of 36 parasite specimens were found aggregated near the cloacal aperture of eight pelagic thresher sharks caught as bycatch by multifilament tuna longliner MFV Blue Marlin during July 2015 and February 2016 voyages in Andaman and Nicobar waters. This is the first report of ectoparasite from the Indian EEZ of the Andaman Sea.
\end{abstract}

Keywords: Andaman Sea; ectoparasite; first report; MFV Blue Marlin; shark host

ABSTRAK

Penyelidikan ini melaporkan kewujudan parasit pandarid, Echthrogaleus denticulatus sebagai ektoparasit kepada pelagik yu ekor panjang (Alopias pelagicus) dari EEZ India Laut Andaman. Sejumlah 36 spesimen parasit ditemui terkumpul berhampiran sudut pembukaan pada lapan pelagik yu ekor panjang yang ditangkap sebagai penampan pelbagai filamen tuna MFV Blue Marlin sepanjang pelayaran bulan Julai 2015 dan Februari 2016 di perairan Andaman dan Nicobar. Ini adalah laporan pertama mengenai ektoparasit dari EEZ India Laut Andaman.

Kata kunci: Ektoparasit; hos yu; laporan pertama; Laut Andaman; MFV Blue Marlin

\section{INTRODUCTION}

The Exclusive Economic Zone (EEZ) of Andaman and Nicobar Islands is about 0.6 million sq $\mathrm{km}$ which is $30 \%$ of the total EEZ of India. The marine ecosystem of these islands consists of mangroves, coral reefs and invisible banks. It is one of the greatest archipelagoes in the world and has a highly diversified marine fauna and may be regarded as a hotspot of biodiversity. Pelagic sharks (including the pelagic thresher shark) contribute $932 \mathrm{t}$ (ca. 3\%) of the total landings of 36,980 t (Anon 2015). The pelagic thresher (Alopias pelagicus Nakamura 1935) is a large lamniform shark of the family, Alopiidae. They are found in all temperate and tropical oceans and are listed as vulnerable to extinction by the International Union for Conservation of Nature (IUCN) (Reardon et al. 2009). Although a few studies like distribution, abundance and diversity of oceanic sharks (Sinha et al. 2010) and biological studies have been carried out on the pelagic thresher sharks of this region by Kar et al. (2011), there is no study on the parasites of the pelagic thresher sharks.

The present study reports Echthrogaleus denticulatus (Smith 1874) as an ectoparasite on Alopias pelagicus from the Andaman and Nicobar waters. E. denticulatus is a member of the Pandaridae family, which comprises about 50 species of Siphonostomatoid copepods, exclusively parasitic on the body surface of elasmobranchs. The method of pandarus species attaching to their shark host was studied by Benz (1992). E. denticulatus was originally described by Thomson (1889) as Dinematura neozealanica and was later transferred to the genus Echthrogaleus by Basset-Smith (1899). E. denticulatus has a wide distribution, having been reported from at least nine different shark species, in the Atlantic, Pacific and Indian Oceans (Cressey 1967; Hewitt 1979; Izawa 2010; Oldewage \& Smale 1993; Pilla 1985; Shiino 1954; Smith 1874; Watchariya et al. 2009). E. denticulatus was reported on A. pelagicus from the Indian Ocean (Madagascar coast), South African coast, north-eastern Brazil, Thailand and Oman waters (Cressey 1867; Dippenaar 2004; Henderson et al. 2013; Santander-Neto \& Lessa 2013; Watchariya et al. 2009). Hence, this study on the occurrence of $E$. denticualtus as an ectoparasite on Alopias pelagicus from the Indian EEZ of Andaman Sea provides a new distribution record for the species.

\section{MATERIALS AND METHODS}

The copepod parasites were collected from the pelagic thresher sharks caught as bycatch of the vessel M.F.V. Blue Marlin belonging to Fishery Survey of India, Port Blair during July 2015 and February 2016 voyages in Andaman and Nicobar waters. The parasites collected were washed in freshwater and stored in $70 \%$ ethanol for further studies. Photography was made using a Stereomicroscope 
(Leica M 205, DFC 500). Selected copepod specimens were soaked in lactophenol for $24 \mathrm{~h}$ before dissection and observations were carried out using the method proposed by Humes and Gooding (1964). The identity of the parasite specimens was established based on the keys to the family Pandaridae provided by Cressey (1967), Hewitt (1967) and Pillai (1985). The parasite specimens were deposited in the museum of Zonal base of Fishery Survey of India, Port Blair (Referral No. MUS.FSI.PB/EBP/03/2016).

\section{RESULTS}

The parasites were found clustered around the cloacal aperture of the pelagic thresher shark and were of upstream orientation (Figure 1). Small wounds were found in the area when parasites were detached. Fifteen sharks were observed, out of which eight were found to be infested with parasites. The pre-caudal length (PCL) of the sharks ranged from 103 to $139 \mathrm{~cm}$ and weight from 30 to 55 $\mathrm{kg}$. In total, 36 parasites were collected. All the collected parasite specimens were females of length range 10.8 to $16.7 \mathrm{~mm}$ total length (TL). Many parasites were lost before collection due to struggling of fish, handling of large fish, washing of deck to clear the deck from slime etc. The sharks were attended after clearing all the fishes mainly tunas and debris from the deck.

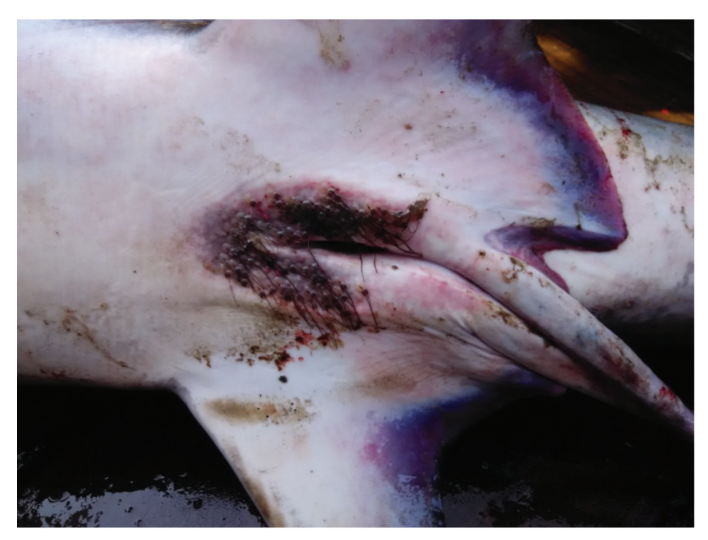

FIGURE 1. Cloaca of Alopias pelagicus showing parasite infestation

\section{SYSTEMATICS}

Class: Maxillopoda Dhal, 1956

Order: Siphonostomatoida Thorell, 1859

Family: Pandaridae Milne Edwards, 1840

\section{Genus: Echthrogaleus Steenstrup and Lütken, 1861}

\section{Echthrogaleus denticulatus Smith, 1874}

Diagnosis Posterior border of dorsal plates prominently denticulate, fourth dorsal thoracic plate does not conceal even half the length of the genital segment, posterior margin of the genital segment is roughly pointed and the fifth leg dorsally visible.

\section{DESCRIPTION OF THE SPECIMEN FROM THE INDIAN EEZ OF ANDAMAN SEA}

Female (Figure 2a\&b) TL $16.73 \mathrm{~mm}$ The cephalothorax is wider than long, laterally rounded and with a flange on either side. Frontal plate is distinct. The cephalothorax divided into various zones by a pair of longitudinal ribs. Second and third segments fused. Lateral margins of dorsal plates are rounded and smooth. The posterior lateral side rounded and slightly extends over the fourth thoracic segment. Fourth thoracic plate large, antero-lateral angle expanded as spine-like projections. Postero-lateral has angles rounded and projecting posteriorly. The plate is nearly divided into equal halves by a posterior median sinus which deep and narrow. Posterior and median margins of the plate are denticulate. Genital segment posteriorly with wide median sinus, lateral lobes very large and distally rounded, median lobe situated within the sinus, distally broader and rounded. From dorsal view the tip of the fifth leg visible, with a stout spine and three pectinate setae. Abdomen single segmented, sub-rectangular slightly narrowing posteriorly. Caudal rami are semicircular and seen on the lateral side of the posterior margin of the abdomen. Each ramus is armed with four spines with short setae.

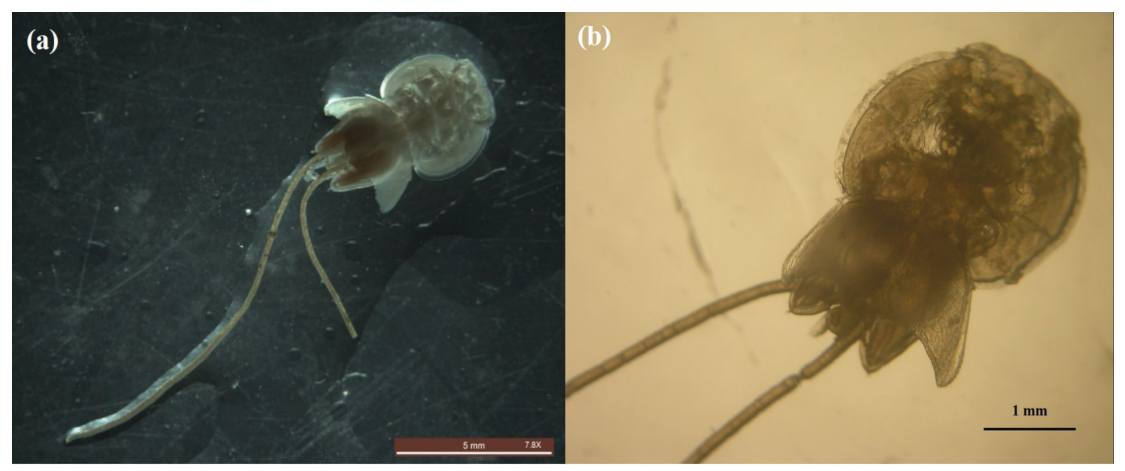

FIGURE 2. Photomicrograph of Echthrogaleus denticulatus (a) Full view (b) Cephalothorax 


\section{DISCUSSION}

Echthrogaleus denticulatus has a close resemblance with E.pellucidus Shiino (1963). According to Shiino (1963), E. pellucidus has transparent integument, its second and third thoracic segments are coalesced at least in the adult. The hind part of the body from the fourth segment is no longer than the anterior part; dorsal plates of the fourth segment do not extend beyond the middle of the genital segment and are bordered with recurved spines on all sides except the front margin. The claw of the maxilliped is bifid and the first three pairs of legs are furnished with bilaterally arranged hairs instead of multiserial ones. Hewitt (1967) gave a clear description of E. denticualtus from New Zealand waters. He mentioned that Dinematura neozealanica Thomson, 1889 is a synonym of E. denticulatus and Pandarus armatus (Heller) by Thomson (1889) is probably male E. denticulatus. The present specimen morphometrically matches well with the description of E. denticulatus by Cressey (1967), Hewitt (1967) and Pillai (1985).

How Pandarid parasite attaches to their shark host was studied by (Benz 1992). Even though not much physical damage was found to be caused by this parasite to the host, the impact of infestation by E. deticualtus on the $A$. pelagicus needs further investigation to estimate the extent of damage and incapacitation inflicted to the host. The parasite assemblage on fishes may provide information about their life cycle, movements and stock identity (Mc Kenzie \& Abaunza 1998).

In the present study, not much observation could be made on host-parasite interactions. Further, most of the previous studies on E. denticulatus are mainly new reports and taxonomical description (Hewitt 1967). Majority of the parasites were found aggregated near the cloacal aperture of the pelagic thresher shark and were of upstream orientation. The extent of damage caused and its effect on the hosts health by this ectoparasite is not known as it is difficult to ascertain the normal health condition of this oceanic shark.

Echthrogaleus denticulatus has been reported from the pelagic thresher sharks of the Southern Africa (Dippenaar 2004), Thailand's EEZ of Andaman sea (Watchariya et al. 2009) and North-eastern Brazil (Santander-neto \& Lessa 2013) and from the west coast of India (Pillai 1985). Asok Kumar (1990) reported the presence of E. denticulatus from Eulamia dussumeri and E. ellioti from Kerala coast, along southwest coast of India. The present study reports the occurrence of $E$. denticulatus from the Indian EEZ of Andaman Sea for the first time, confirming the range extension of the species to south-east of Bay of Bengal, which was formerly reported mainly from the Pacific Ocean, Atlantic Ocean, Madagascar, west coast of India and Thailand's EEZ of Andaman Sea.

\section{ACKNOWLEDGEMENTS}

The authors are thankful to the Director General, Fishery Survey of India, Mumbai for his encouragement during the study period. They also sincerely thank the Officer-in- charge, Zoological Survey of India, Port Blair for providing the Stereo zoom microscope facility and Dr. Tamal Mondal for helping in photography. Furthermore, the authors are thankful to the anonymous reviewers for the betterment of the manuscript. The support rendered by the Scientists of FSI, Port Blair and the staff/officers of the MFV Blue Marlin are thankfully acknowledged.

\section{REFERENCES}

Anon. 2015. Fisheries in Andaman and Nicobar Islands. Directorate of Fisheries, Andaman and Nicobar Administration, Port Blair.

Asok Kumar, K. 1990. Studies on Copepod Parasites on elasmobranches of Kerala coast. PhD. Thesis, Cochin University of Science and Technology. Cochin, India (Unpublished).

Bassett-Smith, P.W. 1899. A systematic description of parasitic Copepoda found on fishes with an enumeration of the known species. Proc. Zool. Soc. Lond. pp. 438-507.

Benz, G.W. 1992. How Pandarus species (Copepoda: Pandaridae) attach to their shark hosts. J. Parasitol. 78(2): 368-370.

Cressey, R.F. 1967. Revision of the family Pandaridae (Copepoda: Caligoida). Proc. U.S. Natl. Mus. 121: 1-133. doi: 10.5479/ si.00963801.121-3570.1.

Dippenaar, S.M. 2004. Reported siphonostomatoid copepods parasitic on marine fishes of Southern Africa. Crustaceana 77(11): 1281-1328.

Henderson, A.C., Reeve, A.J. \& Tang, D. 2013. Parasitic copepods from some northern Indian Ocean elasmobranchs. Mar. Biodivers. 6: e44. DOI: 10.1017/S1755267213000195.

Hewitt, G.C. 1979. Eight species of parasitic Copepoda on a white shark. N. Z. J. Mar. Freshwater Res. 13(1): 171-171.

Hewitt, G.C. 1967. Echthrogaleus denticulatus smith (copepoda, pandaridae) in New Zealand waters. N. Z. J. Mar. Freshwater Res. 1(3): 341-351: doi:10.1080/00288330.1967.9515210.

Humes, A.G. \& Gooding, R.U. 1964. A method for studying the external anatomy of copepods. Crustaceana 6: 238-240.

Izawa, K. 2010. Redescription of eight species of parasitic copepods (Siphonostomatoida, Pandaridae) infecting Japanese Elasmobranchs. Crustaceana 83: 313-341.

Kar, A.B., Govindaraj, K., Prasad, G.V.A. \& Ramalingam, L. 2011. Bycatch in tuna longline fishery in the Indian EEZ around Andaman and Nicobar Islands. IOTC-2011WPEB07-19.

McKenzie, K. \& Abaunza, P. 1998. Parasites as biological tags for stock discrimination of marine fish: A guide to procedures and methods. Fish Res. 38: 45-46.

Oldewage, W.H. \& Smale, M.J .1993. Occurrence of piscine parasitic copepods (Crustacea) on sharks taken mainly off Cape Recife, South Africa. South Afr. J. Marine Sci. 13: 309-312. doi:10.2989/025776193784287310.

Pillai, N.K. 1985. The Fauna of India. Copepod Parasites of Marine Fishes. Zoological Society India, Calcutta.

Reardon, M., Márquez, F., Trejo, T. \& Clarke, S.C. 2009. Alopias pelagicus. The IUCN Red List of threatened species: e.T161597A5460720. http://dx.doi.org/10.2305/IUCN. UK.2009-2.RLTS.T161597A5460720.en. Accessed on 19 November 2015.

Santander-neto, J. \& Lessa, R. 2013. Hermaphroditic smalleye droundray (Urotrygon microphthalmum) from north-eastern Brazil.Mar.Biodivers.Rec. 6: e60.https://dx.doi.org/10.1017/ S1755267213000353. 
Shiino, S.M. 1954. Copepods parasitic on Japanese fishes. 5. Five species of the family Pandaridae. Rep. Fac. Fish. Prefect. Univ. Mie. 1: 291-332.

Shiino, S.M. 1963. Parasitic copepods of Eastern. Pacific fishes. 3. Echthrogaleus pellucidus Sp.nov., Rep. Fac. Fish.Prefect. Univ. Mie. 4: 357-368.

Smith, S.I. 1874. Report upon the invertebrate animals of the Vineyard Sound and adjacent waters. Rep.Comm. Fish. and Fisher. 1871 \& 1872: 478.

Sinha, M.K., Paul Pandian, P., Pattnayak, S.K. \& Kar, A.B. 2010. Spatio-temporal distribution, abundance and diversity of oceanic sharks occurring in Andaman and Nicobar waters. Recent Trends in Biodiversity of Andaman and Nicobar Islands, Zoological survey of India. pp. 373-385.

Thomson, G. M. 1889. Parasitic Copepoda of New Zealand. Trans. Proc. N.Z. Inst. 22: 353-376.

Watchariya, P., Phithak, C. \& Thanitha Thapanand, C. 2009. Parasites of deep-sea sharks from the Andaman Sea with six new records of parasites in Thailand. Kasetsart J. (Nat. Sci.) 43: 93-99.
Pradeep, H.D.* \& Swapnil, S.S

Fishery Survey of India

Port Blair Zonal Base, Port Blair

Andaman \& Nicobar Islands

India

Arun Kumar, M.

Department of Ocean Studies and Marine Biology

Pondicherry University, Brookshabad Campus

Post Bag No. 1, Chakkargaon Post

Port Blair- 744112, Andaman Islands

India

*Corresponding author; email: hdpradeep@gmail.com

Received: 7 May 2016

Accepted: 29 March 2017 